DOI 10.36622/VSTU.2021.50.2.006

UDC 624.21 .09

V. A. Shendrik ${ }^{1}$

\title{
STRUCTURAL EVALUATION OF REINFORCED CONCRETE COLUMN WITH COMPOSITE GFRP SHELL - A STRUCTURAL ELEMENT OF BRIDGE PIER
}

\author{
Saint Petersburg State University of Architecture and Civil Engineering ${ }^{1}$ \\ Russia, Saint Petersburg
}

${ }^{1}$ PhD student of the Dept. of Roads, Bridges and Tunnels, e-mail: vicinshendrik@yandex.ru

Statement of the problem. It's considered the problem of developing a methodology for structural evaluation of hybrid design - a reinforced concrete column combined with external composite GFRP (glass-fiber-reinforced-plastic) shell. This hybrid design is intended for bridge piers.

Results. As a result of a study, theoretical relationships were formulated to determine the longitudinal and transverse stresses and relative deformations of hybrid column structural elements. The developed formulas take into account the cooperation of triaxial compressed concrete core and an anisotropic composite GFRP shell.

Conclusions. The obtained theoretical dependences of the hybrid column's elements behavior make it possible to develop a structural evaluation methodology of bridge piers hybrid columns. The findings of the investigation are proposed to be applied in the structural evaluations of the bridges piers hybrid columns with composite GFRP elements.

Keywords: bridges, support pillars of bridges, composite materials, glass-fiber-reinforced-plastic-tubes, hybrid structures.

Introduction. Over the past few decades recent, there has been a considerable rise in the load on the structures of bridge structures, thus there is a need for their load-bearing capacity to be icnreased. Besides, the structures of bridge piers, made mainly of reinforced concrete, are being negatively impacted by the environment. Therefore, intensive corrosion occurs leading to a significant reduction in their durability and reliability [13]. Currently, there is an inadequate service life of bridge structures due to rising loads and traffic intensity $[5,15]$. These make it necessary to increase the load-bearing capacity and durability of bridge structures. Composite materials are presently known to have greater durability compared to the commonly used concrete and steel $[9,14]$, which can considerably increase the service life of building structures. 
In particular, those composites which consist of glass fibers impregnated with polymeric binders are not inferior to reinforced concrete in strength and rigidity, and in terms of resistance to aggressive environmental factors, such fiberglass can outperform reinforced concrete and metals. The use of hybrid structures in bridge construction combining the advantages of the commonly used in reinforced concrete supports and innovative fiberglass would potentially increase both the load-bearing capacity (due to the high strength of $\mathrm{KM}$ ) and durability of bridge structures due to resistance to negative environmental impact. The introduction of hybrid structures in the supports of bridge structures caters for the current needs of the bridge industry. As this involves the use of new materials, the ongoing study discusses the operation of hybrid struts only in bridge piers on small and medium-sized overpasses, overpasses and overground pedestrian crossings, except the supports of structures across water barriers or highlands.

The nuances of this research area are characterized by publications of domestic and overseas scientists. Data on the properties of composites has been presented by V. V. Vasiliev and Yu. M. Tarnopolsky [9], A. A. Berlin and M. L. Kerber [14]. Criteria for the strength of concrete have been developed in the studies by O. Ya. Berg [2, 3], Yu. N. Malashkin [12], N. I. Karpenko [7, 8], A. V. Yashin [16]. The strength of reinforced concrete struts has been investigated by A.A. Gvozdev [4], L. K. Luksha [11]. A. N. Yashnov, B. V. Pyrinov, A. N. Ivanov [6] developed the span structures of bridges with fiberglass beams. Overseas scientists D. Kendall [20], C. Hamrick [18] are actively engaged in the introduction of composite materials in the span structures of bridges. T. A. Hoffard and L. J. Malvar [19], H. M. Dawood and M. ElGawady [17], P. B. Potyrala [21], R. J. Watson [22] have examined the operation of reinforced concrete columns reinforced with rigid shells.

Presently composite materials in bridge construction are largely used in the construction of span structures. A considerable roadblock for using fiberglass in the construction of supports of bridge structures is the lack of methods for their calculation. Hence composites are still commonly used in the supports of bridge structures only for strengthening load-bearing structures. Currently there is a need to investigate the specifics of the work of hybrid fiberglass-reinforced concrete structural elements of the supports of bridge structures and to design a method for calculating their load-bearing capacity. The objective of the study is to formulate theoretical dependences for estimating the load-bearing capacity of a hybrid stand with a composite shell.

1. Design of a hybrid rack for supports of bridge constructions. In order to address the objective of the study, the design of a reinforced concrete support for bridge structures was developed and improved as shown in Fig. 1 a. 
a)

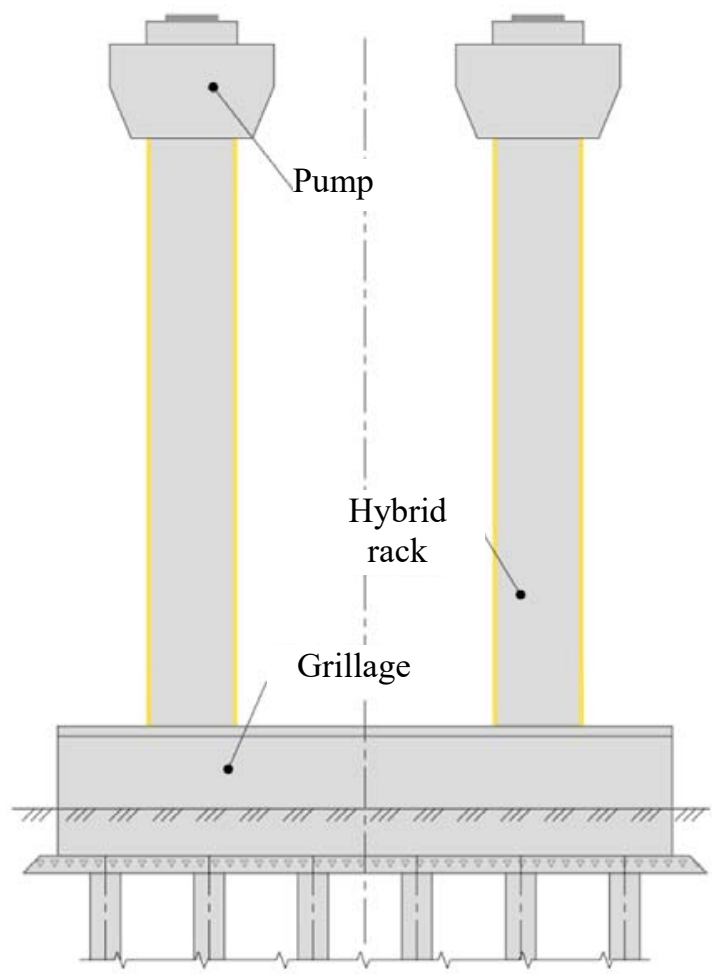

b)

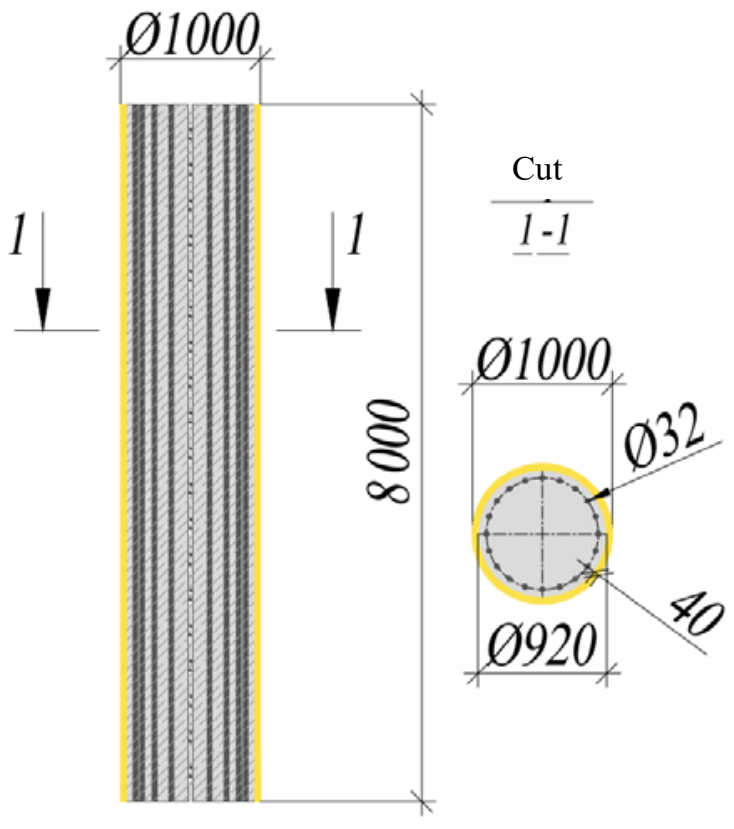

Fig. 1. Suggested design of a rack support of bridge constructions: a) the general look;

b) hybrid reinforced concrete rack whose construction includes an outer fiberglass shell

What makes this structure different from the applied analogs of reinforced concrete rack supports are hybrid racks whose external concrete surface is enclosed in a fiberglass cover (similarly to a fixed timbering). Reinforced concrete structures are known where the load-bearing capacity of the concrete core increases considerably $[4,10,11]$. But the methods of their calculation are made for racks with steel shells and cannot be employed for calculating racks with fiberglass shell having anisotropic properties. Additionally, steel shells tend to have a low resistance to corrosion. Therefore from the perspective of durability it is most viable to use the fiberglass covers capable to resist long-term aggressive influences of external environment in racks of supports of bridge constructions. A hybrid reinforced concrete rack with an outer diameter of $D=1000 \mathrm{~mm}$ and a height of $L=8$ meters was considered. The hybrid rack as an additional load-bearing structural element has an outer fiberglass shell (Fig. 1 b) with an inner diameter $d=920 \mathrm{~mm}$ and a wall thickness $\delta=40 \mathrm{~mm}$.

\section{Theoretical dependences for identifying the lateral pressure of the concrete core on}

the shell of the hybrid rack. When the hybrid rack is compressed, extra transverse stresses 
of interaction of the concrete core with the anisotropic composite shell occur. Hence in order to calculate the load-bearing capacity of the hybrid rack, it is necessary to consider the additional strengthening of the strength of the enclosed concrete core, which is in a three-axis stress-strain . As the shell is close to the concrete of the hybrid rack, when the rack is compressed, its outer shell prevents the free transverse expansion of the concrete core. This being the case, the concrete rod of the hybrid rack transmits the internal stresses arising in it not only to the base, but also to the outer fiberglass shell (Fig. 2). Therefore the concrete core works in conditions of non-uniaxial, but triaxial (volumetric) compression, which causes a significant increase in the load-bearing capacity of the hybrid rack.

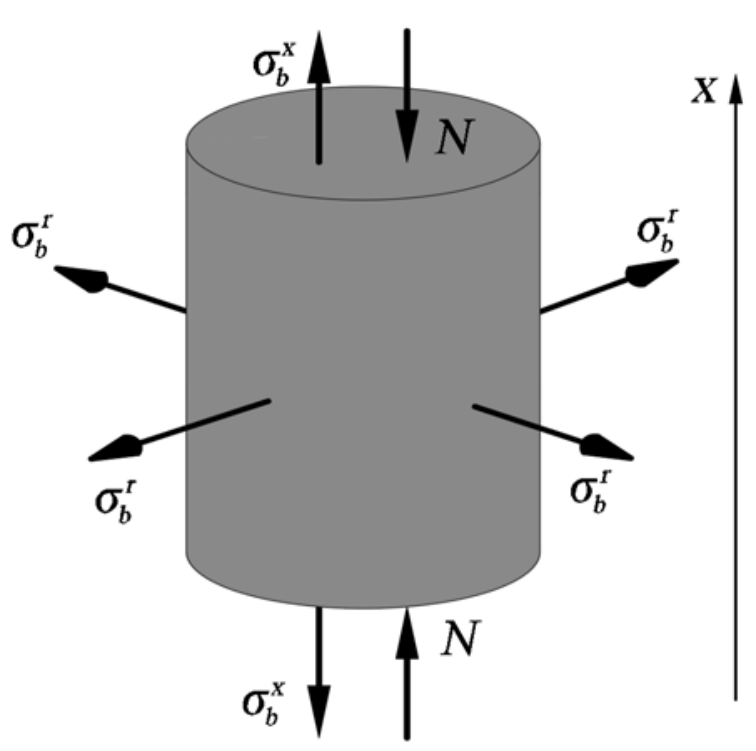

a)

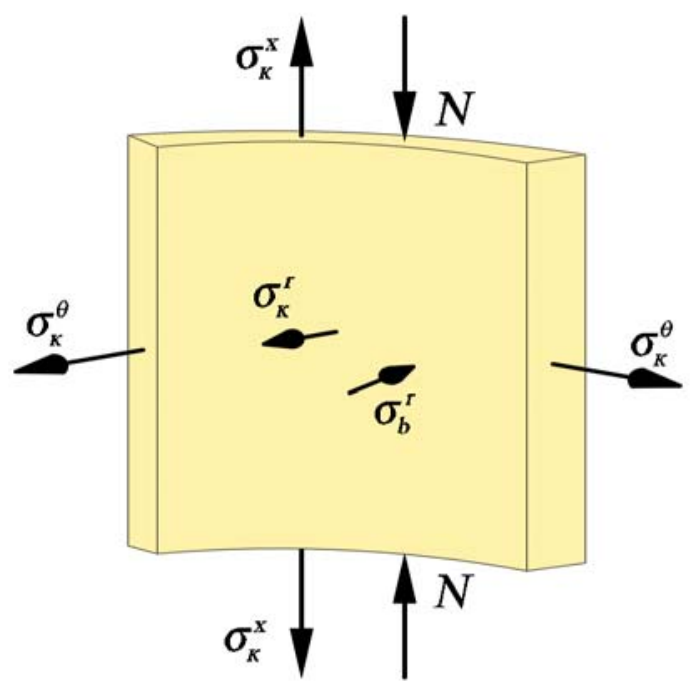

б)

Fig. 2. Three-dimensional stress-strain of the elements of the hybrid rack:

a) concrete core, b) fiberglass shell

Fig. 2 denotes $N$ as the external longitudinal force from the central compression, $\sigma_{\mathrm{K}}^{x}, \sigma_{b}^{x}$ as internal longitudinal stresses of the fiberglass shell and concrete core, $\sigma_{\mathrm{K}}^{r}, \sigma_{b}^{r}$ as internal transverse (radial) stresses of the fiberglass shell and concrete core, $\sigma_{\mathrm{K}}^{\theta}$ as internal tangential (tangential) stresses of the fiberglass shell.

In order to evaluate the load-bearing capacity of the hybrid rack structure, it is necessary to identify the stress of its structural elements. The annular (tangential) stresses in the middle of the annular cross section of the shell are equal to [1]: 


$$
\sigma_{\mathrm{K}}^{\theta}=p \times \frac{r_{b}+\delta 2}{\delta},
$$

where $p$ is the pressure of a concrete kernel on a wall of a cover (in our case $p=\sigma_{b}^{r}=-\sigma_{\mathrm{K}}^{r}$ ), $\delta$ is the thickness of the wall of the shell, $r_{b}$ is the radius of the concrete core (corresponding to the internal radius of the shell).

In order to identify the radial pressure on the shell wall $p$, it is necessary to design the dependences of the interaction of the core stresses with the shell. As the core and the shell are included in the joint work and are close to each other, their relative deformations are identical. The equation of equilibrium of elastic relative deformations in the transverse direction takes the form:

$$
\varepsilon_{\mathrm{K}}^{r}=\varepsilon_{b}^{r},
$$

where $\varepsilon_{\mathrm{K}}^{r}, \varepsilon_{b}^{r}$ are transverse relative deformations of the concrete core and fiberglass shell from the action of radial pressure $p$.

According to the theory of elasticity, the equations for calculating the relative deformations, considering the properties of concrete and fiberglass, are the following:

$$
\begin{gathered}
\varepsilon_{\mathrm{K}}^{r}=\frac{1}{E_{\mathrm{K}}^{r}} \times\left[\sigma_{\mathrm{K}}^{\theta}+\mu_{\mathrm{K}}^{x} \sigma_{\mathrm{K}}^{x}\right], \\
\varepsilon_{b}^{r}=\frac{-1}{E_{b}} \times\left[p-\mu_{b} \times\left(\sigma_{b}^{x}+p\right)\right]=-\left[\frac{1-\mu_{b}}{E_{b}} \times p-\frac{\mu_{b}}{E_{b}} \sigma_{b}^{x}\right],
\end{gathered}
$$

where $E_{b}$ is the elasticity modulus of concrete, $\mu_{b}$ is the Poisson coefficient of concrete, $E_{\mathrm{K}}^{r}$ is the elasticity modulus of fiberglass in the transverse direction, $\mu_{\mathrm{K}}^{x}$ is the Poisson coefficient of fiberglass in the longitudinal direction.

As the transverse relative deformations at the interface between the materials of the core and the shell are equal and transmitted evenly, the transverse displacements of concrete and fiberglass are also equal to:

$$
\varepsilon_{\mathrm{K}}^{r} \times\left(r_{b}+\delta 2\right)=\varepsilon_{b}^{r} \times r_{b} .
$$

The condition of equality of relative deformations of the shell and the core in the transverse direction is obtained by substituting expressions (3) and (4) in equation (2):

$$
\frac{1}{E_{\mathrm{K}}^{r}} \times\left[\sigma_{\mathrm{K}}^{\theta}+\mu_{\mathrm{K}}^{x} \sigma_{\mathrm{K}}^{x}\right]=-\left[\frac{1-\mu_{b}}{E_{b}} \times p-\frac{\mu_{b}}{E_{b}} \sigma_{b}^{x}\right] .
$$

If the following denotations are used

$$
\begin{aligned}
& t=\frac{r_{b}+\delta 2}{r_{b}}, \\
& \bar{R}=\frac{r_{b}+\delta 2}{\delta},
\end{aligned}
$$

after substituting expression (1) and some transformations into it, equality (6) takes the form: 


$$
\left(\frac{t \bar{R}}{E_{\mathrm{K}}^{r}}+\frac{1-\mu_{b}}{E_{b}}\right) \times p=\frac{\mu_{b}}{E_{b}} \sigma_{b}^{x}-\frac{t \mu_{\mathrm{K}}^{x}}{E_{\mathrm{K}}^{r}} \sigma_{\mathrm{K}}^{x} .
$$

Hence it is possible to express the required transverse (radial) pressure $p$ from the concrete core on the fiberglass shell:

$$
p=\frac{1}{t \bar{R}+\frac{E_{\mathrm{K}}^{r}}{E_{b}} \times\left(1-\mu_{b}\right)} \times\left[\frac{\mu_{b} E_{\mathrm{K}}^{r}}{E_{b}} \sigma_{b}^{x}-t \nu_{\mathrm{K}}^{x} \sigma_{\mathrm{K}}^{x}\right] .
$$

The resulting formula allows us to calculate the pressure $p$, which makes it possible to identify the limiting factor of the hybrid rack, i.e., the stress-strain of the shell in the transverse direction.

\section{Formation of dependences identifying longitudinal stresses of structural elements of a}

hybrid rack. While exposed to a compressive load evenly distributed over the cross section of the hybrid rack (i.e., both the concrete core and the shell), the vertical relative deformations in the longitudinal direction (along the $\mathrm{x}$-axis) of the core and the fiberglass shell are identical:

$$
\varepsilon_{\mathrm{K}}^{x}=\varepsilon_{b}^{x},
$$

where $\varepsilon_{\mathrm{K}}^{x}, \varepsilon_{b}^{x}$ are longitudinal relative deformations of the core and shell under the influence of longitudinal compression load $N$.

The relative deformations of the elements of the hybrid rack in the longitudinal direction are given by the following dependences:

$$
\begin{aligned}
& \varepsilon_{b}^{x}=\frac{1}{E_{b}} \times\left[\sigma_{b}^{x}-2 \mu_{b} \times p\right], \\
& \varepsilon_{\mathrm{K}}^{x}=\frac{1}{E_{\mathrm{K}}^{x}} \times\left[\sigma_{\mathrm{K}}^{x}+\mu_{\mathrm{\kappa}}^{r} \sigma_{\mathrm{\kappa}}^{\theta}\right],
\end{aligned}
$$

where $E_{\mathrm{K}}^{x}$ is the elasticity modulus of of fiberglass in the longitudinal direction, $\mu_{\mathrm{K}}^{r}$ is the Poisson's ratio of fiberglass in the transverse direction.

The equilibrium condition of the structural elements of the hybrid rack in the longitudinal direction is given by substituting equations (12) and (13) into expression (11):

$$
\frac{1}{E_{b}} \times\left[\sigma_{b}^{x}-2 \mu_{b} \times p\right]=\frac{1}{E_{\mathrm{K}}^{x}} \times\left[\sigma_{\mathrm{K}}^{x}+\mu_{\mathrm{K}}^{r} \sigma_{\mathrm{K}}^{\theta}\right] .
$$

Given (1) and (8), the expression (14) is transformed:

$$
\frac{1}{E_{b}} \times\left[\sigma_{b}^{x}-2 \mu_{b} \times p\right]=\frac{1}{E_{\mathrm{K}}^{x}} \times\left[\sigma_{\mathrm{K}}^{x}+\mu_{\mathrm{K}}^{r} \times p \times \bar{R}\right] .
$$

By performing the following mathematical transformations, it is possible to express the longitudinal stresses of the concrete core of the hybrid rack $\sigma_{b}^{x}$ :

$$
\begin{aligned}
& \frac{1}{E_{b}} \times\left[\sigma_{b}^{x}-2 \mu_{b} \times p\right]=\frac{1}{E_{\mathrm{K}}^{x}} \times\left[\sigma_{\mathrm{K}}^{x}+\mu_{\mathrm{K}}^{r} \bar{R} p\right], \\
& \frac{1}{E_{\mathrm{K}}^{x}} \times\left[\sigma_{b}^{x}-2 \mu_{b} \times p\right]=\frac{1}{E_{b}} \times\left[\sigma_{\mathrm{K}}^{x}+\mu_{\mathrm{K}}^{r} \bar{R} p\right], \\
& \sigma_{b}^{x}-2 \mu_{b} p=\frac{E_{b}}{E_{\mathrm{K}}^{x}} \times\left[\sigma_{\mathrm{K}}^{x}+\mu_{\mathrm{K}}^{r} \bar{R} p\right],
\end{aligned}
$$




$$
\begin{aligned}
& \sigma_{b}^{x}=\frac{E_{b}}{E_{\mathrm{K}}^{x}} \times\left[\sigma_{\mathrm{\kappa}}^{x}+\mu_{\mathrm{\kappa}}^{r} \bar{R} p\right]+2 \mu_{b} p, \\
& \sigma_{b}^{x}=\frac{E_{b}}{E_{\mathrm{K}}^{x}} \sigma_{\mathrm{\kappa}}^{x}+\frac{E_{b}}{E_{\mathrm{K}}^{x}} \mu_{\mathrm{\kappa}}^{r} \bar{R} p+2 \mu_{b} p .
\end{aligned}
$$

Let

$$
a=\frac{1}{t \bar{R}+\frac{E_{K}^{r}}{E_{b}} \times\left(1-\mu_{b}\right)},
$$

the expression(10) takes the following form:

$$
p=a \mu_{b} \frac{E_{\mathrm{K}}^{r}}{E_{b}} \sigma_{b}^{x}-\operatorname{at} \mu_{\mathrm{K}}^{x} \sigma_{\mathrm{K}}^{x} .
$$

Inserting (22) into equation (20), we get:

$$
\sigma_{b}^{x}=\frac{E_{b}}{E_{\mathrm{K}}^{x}} \sigma_{\mathrm{\kappa}}^{x}+\frac{E_{\mathrm{K}}^{r}}{E_{\mathrm{K}}^{x}} \mu_{\mathrm{\kappa}}^{r} \bar{R} a \mu_{b} \sigma_{b}^{x}-\frac{E_{b}}{E_{\mathrm{K}}^{x}} \mu_{\mathrm{\kappa}}^{r} \bar{R} \mathrm{at} \mu_{\mathrm{\kappa}}^{x} \sigma_{\mathrm{\kappa}}^{x}+2 a \mu_{b}^{2} \frac{E_{\mathrm{K}}^{r}}{E_{b}} \sigma_{b}^{x}-2 \mu_{b} \mathrm{at} \mu_{\mathrm{\kappa}}^{x} \sigma_{\mathrm{K}}^{x} .
$$

In order to express the stresses of the structural elements of the hybrid rack in the longitudinal direction, let us introduce:

$$
K_{\mathrm{K}} \times \sigma_{\mathrm{K}}^{x}=K_{b} \times \sigma_{b}^{x},
$$

where $K_{\kappa}$ and $K_{b}$ are obtained based on (23) and are equal to:

$$
\begin{aligned}
& K_{\mathrm{K}}=\frac{E_{b}}{E_{\mathrm{K}}^{x}}-\frac{E_{b}}{E_{\mathrm{K}}^{x}} \mu_{\mathrm{K}}^{r} \bar{R} \mathrm{at} \mu_{\mathrm{K}}^{x}-2 \mu_{b} \text { at } \mu_{\mathrm{K}}^{x}, \\
& K_{b}=1-\frac{E_{\mathrm{K}}^{r}}{E_{\mathrm{K}}^{x}} \mu_{\mathrm{K}}^{r} \bar{R} a \mu_{b}-2 a \mu_{b}^{2} \frac{E_{\mathrm{K}}^{r}}{E_{b}} .
\end{aligned}
$$

Then the original stresses of the shell and core of the hybrid rack in the longitudinal direction are equal to:

$$
\begin{aligned}
& \sigma_{\mathrm{K}}^{x}=\frac{K_{b}}{K_{\mathrm{K}}} \times \sigma_{b}^{x}, \\
& \sigma_{b}^{x}=\frac{K_{\mathrm{K}}}{K_{b}} \times \sigma_{\mathrm{K}}^{x} .
\end{aligned}
$$

Then it is possible to calculate the compressive load $N$ acting at the stress $\sigma_{\mathrm{K}}^{x}, \sigma_{b}^{x}$ using one of the below formulas:

$$
\begin{aligned}
N=2 \pi \times\left(r_{b}+\delta 2\right) \times \delta \times \sigma_{\mathrm{K}}^{x}+\pi \times r_{b}^{2} \times \sigma_{b}^{x}, \\
N=2 \pi \times\left(r_{b}+\delta 2\right) \times \delta \times \sigma_{\mathrm{K}}^{x}+\pi \times r_{b}^{2} \times \frac{K_{\mathrm{K}}}{K_{b}} \times \sigma_{\mathrm{K}}^{x}, \\
N=2 \pi \times\left(r_{b}+\delta 2\right) \times \delta \times \frac{K_{b}}{K_{\mathrm{K}}} \times \sigma_{b}^{x}+\pi \times r_{b}^{2} \times \sigma_{b}^{x} .
\end{aligned}
$$

Apart from dependences (27) and (28), the longitudinal stresses of the structural elements of the hybrid rack can be calculated from the expressions obtained from equations (30) and (31):

$$
\sigma_{\mathrm{K}}^{x}=\frac{N}{2 \pi \times\left(r_{b}+\delta 2\right) \times \delta+\pi \times r_{b}^{2} \times \frac{K_{\mathrm{K}}}{K_{b}}},
$$




$$
\sigma_{b}^{x}=\frac{N}{2 \pi \times\left(r_{b}+\delta 2\right) \times \delta \times \frac{K_{b}}{K_{\mathrm{K}}}+\pi \times r_{b}^{2}} .
$$

Therefore the dependences of the operation in the elastic stage of the hybrid rack made of fiberglass shell filled with monolithic concrete are obtained.

\section{Estimation of the load-bearing capacity of a hybrid rack under the influence of com-}

pression. The above expressions are compiled according to the parameters of materials characteristic of the elastic stage of their operation, thus they are only valid at the initial stage of loading the rack. In the case of exposure to the rack of a considerable amount of compression load, the concrete goes beyond the elastic stage of operation, as a result of which the stresses calculated by the derived formulas $(22,32,33)$ are unacceptably overestimated. By the time the stresses in the concrete exceed $0.5 \div 0.7 R_{b}$ (prismatic compressive strength), the elasticity modulus of concrete starts changing based on a nonlinear law as the compressive force rises. A well-studied and commonly used method is known for calculating the stresses of concrete during nonlinear operation. A simplified three-line diagram based on the type of Prandtl diagrams (in accordance with SP 63.13330.2018 - "Concrete and Reinforced Concrete Structures") is adopted as a working diagram of the state of concrete, which identifies the relationship between stresses and relative deformations. The stresses of the concrete rod $\sigma \mathrm{b}$ depending on the corresponding relative deformations of the shortening of concrete $\varepsilon_{b}$ are given by the formula:

$$
\sigma_{b}=\left[\left(1-\frac{\sigma_{b 1}}{R_{b}}\right) \times \frac{\varepsilon_{b}-\varepsilon_{b 1}}{\varepsilon_{b 0}-\varepsilon_{b 1}}+\frac{\sigma_{b 1}}{R_{b}}\right] \times R_{b},
$$

where

$$
\begin{aligned}
\sigma_{b 1} & =0,6 \times R_{b}, \\
\varepsilon_{b 1} & =\frac{\sigma_{b 1}}{E_{b}},
\end{aligned}
$$

$\varepsilon_{b 0}$ are the largest longitudinal values of relative deformations of concrete depending on the relative humidity of the surrounding air.

The longitudinal stresses of concrete under volumetric compression increase fairly considerably and can greatly exceed the prismatic strength $R_{b}$. The criteria for the strength of concrete are used to identify he values of stresses where the strength of concrete is maintained under the conditions of triaxial compression. For the case of triaxial compression of concrete, A. A. Gvozdev's strength criterion for bulk compressed concrete is commonly used [4]:

$$
\left[\sigma_{b, 3}^{x}\right]=R_{b}+\beta \times \sigma_{b}^{r},
$$

where $\beta$ is the parameter of the material. 
The results of N. I. Karpenko's experimental-theoretical studies [7] and the results of the later work by other researchers showed that the parameter $\beta$ is not a constant value, but rather is described by the dependence [8]:

$$
\beta=\frac{1+a-a \times \frac{\sigma_{b}^{r}}{\sigma_{b}^{x}}}{b+(f-b) \times \frac{\sigma_{b}^{r}}{\sigma_{b}^{x}}}
$$

where $b=0.096, a=0.5 b, f=1$ are empirical coefficients of concrete.

Note that in the above design, the longitudinal stresses of the shell are always a lot lower than the corresponding ones in concrete due to a considerable difference in their cross-sectional areas. Thus despite the fact that the concrete core operates outside the elastic stage based on the nonlinear law, the shell at the same time operates predominantly elastic (except for the stage of destruction in the transverse direction if it takes place).

Following the calculation of the parameters characterizing the stress-strain of the hybrid rack, the load-bearing capacity of the hybrid rack under the action of compression is evaluated. It is considered that the integrity of the structure of the rack under the action of compression is preserved if the strength conditions for each of its elements are satisfied:

$$
\begin{aligned}
& p<\sigma_{\mathrm{\kappa}, \mathrm{p}}^{r}, \\
& \sigma_{\mathrm{K}}^{x}<\sigma_{\mathrm{K}, \mathrm{c}}^{x}, \\
& \sigma_{b}^{x}<\left[\sigma_{b, 3}^{x}\right],
\end{aligned}
$$

where $\sigma_{\kappa, p}^{r}$ are ultimate tensile transverse stresses from the evenly distributed pressure on the wall of the fiberglass shell $\sigma_{\mathrm{K}, \mathrm{c}}^{x}$ are ultimate stresses while compressing fiberglass in the longitudinal direction.

Checking the durability of a hybrid rack on the bending moment is performed as for a regular reinforced concrete rack of a round section. It is possible to consider the strength characteristics of the fiberglass shell as an additional reinforcement of the structure.

Conclusions. A model of the stress-strain of the hybrid rack intended for supports of bridge constructions is designed and scientifically substantiated. It considers the deformation interaction of a comprehensively compressed concrete core with an anisotropic fiberglass shell. Expressions identifying stresses and relative deformations in the longitudinal and transverse directions during compression of a hybrid stand are formulated. It is found that the concrete core operates outside the elastic stage based on the nonlinear law whereas the shell operates mainly elastically, except the stage of destruction in the transverse direction if it takes place. 
The above results contribute to the development of a calculation method for hybrid reinforced concrete racks with external fiberglass shells. This technique will enable one to estimate the compressive load-bearing capacity considering the nonlinear operation of the concrete core, its interaction with the shell, various parameters of fiberglass in the longitudinal and transverse directions. The proposed design parameters characterize the limit states of each element of the hybrid rack, which in compliance with the requirements of modern regulations ensures the safety, reliability and durability of the designed structure.

\section{References}

1. Aleksandrov A. V., Potapov V. D., Derzhavin B. P. Soprotivlenie materialov [Resistance of materials]. Moscow, Vysshaya shkola Publ., 2008. 559 p.

2. Berg O. Ya., Shcherbakov E. N., Pisanko G. N. Vysokoprochnyi beton [High-strength concrete]. Moscow, Stroiizdat Publ., 1971. 208 p.

3. Berg O. Ya. Fizicheskie osnovy teorii prochnosti betona i zhelezobetona [Physical foundations of the theory of strength of concrete and reinforced concrete]. Moscow, Gosstroiizdat Publ., 1961. 96 p.

4. Gvozdev A. A. Raschet nesushchei sposobnosti konstruktsii po metodu predel'nogo ravnovesiya [Calculation of the load-bearing capacity of structures using the limit equilibrium method]. Moscow, Izd-vo i tip. Stroiizdata, 1949. $280 \mathrm{p}$.

5. Drobyshevskii B. A. Problemy malogo mostostroeniya [Problems of small bridge construction]. Transportnoe stroitel'stvo, 2005, no. 11, pp. 22-24.

6. Ivanov A. N. Sovershenstvovanie konstruktsii i metodiki rascheta proletnykh stroenii mostov s nesushchimi elementami iz kompozitsionnykh materialov. Avtoref. diss. kand. tekhn. nauk [Improvement of the design and calculation methods of bridge spans with load-bearing elements made of composite materials. Cand. eng. sci. diss. abstr.]. Novosibirsk, 2015. 22 p.

7. Karpenko N. I. Obshchie modeli mekhaniki zhelezobetona [General models of reinforced concrete mechanics]. Moscow, Stroiizdat Publ., 1996. 412 p.

8. Karpenko N. I., Karpenko S. N. [Composite criterion of concrete strength under volumetric stress state]. Beton i zhelezobeton - vzglyad v budushchee: tr. III Vserossiiskoi i II Mezhd. konf. po betonu i zhelezobetonu [Proc. "Concrete and reinforced concrete-a look into the future"], 2014, vol. IV, pp. 156-165.

9. V. V. Vasil'ev e.a. Kompozitsionnye materialy: Spravochnik [Composite materials: Reference book]. Moscow, Mashinostroenie Publ., 1990. 510 p.

10. Kikin A. I., Sanzharovskii R. S., Trull' V. A. Konstruktsii iz stal'nykh trub, zapolnennykh betonom [Structures made of steel pipes filled with concrete]. Moscow, Stroiizdat Publ., 1974. 145 p.

11. Luksha L. K. Prochnost' trubobetona [Strength of pipe concrete]. Minsk, Vysheish. Shkola Publ., 1977. 96 p.

12. Malashkin Yu. N. Deformirovanie i razrushenie betona v usloviyakh slozhnykh napryazhennykh sostoyanii. Avtoref. diss. kand. tekhn. nauk [Deformation and destruction of concrete under complex stress conditions. Cand. eng. sci. diss. abstr.]. Moscow, 1984. 38 p. 
13. Ovchinnikova T. S., Marinin A. N., Ovchinnikov I. G. Korroziya i antikorrozionnaya zashchita zhelezobetonnykh mostovykh konstruktsii [Corrosion and corrosion protection of reinforced concrete bridge structures]. Internet-zhurnal «Naukovedenie», 2014, no. 5 (24), pp. 1-25. Available at: https://naukovedenie.ru/ PDF/06KO514.pdf.

14. Kerber M. L. e.a. Polimernye kompozitsionnye materialy: struktura, svoistva, tekhnologiya [Polymer composite materials: structure, properties, technology]. Saint-Petersburg, Professiya Publ., 2008. 557 p.

15. Solov'ev B. V., Malyasova E. N. Osobennosti proektirovaniya i ekspluatatsii zhelezobetonnykh avtodorozhnykh mostov s uchetom vozrosshikh nagruzok ot transporta [Features of the design and operation of reinforced concrete road bridges, taking into account the increased loads from transport]. Vestnik YuzhnoUral'skogo gos. un-ta. Ser.: Stroitel'stvo i arkhitektura, 2009, no. 35 (168), pp. 14-15.

16. Yashin A. V. [Criteria for strength and deformation of concrete under simple loading for various types of stress state]. Trudy Akad. stroitel'stva i arkhitektury SSSR. Nauch.-issled. in-t betona i zhelezobetona "NIIZhB". Vyp.39: Raschet i konstruirovanie zhelezobetonnykh konstruktsii [Proc. of the Acad. construction and architecture of the USSR. Scientific research. in-t concrete and reinforced concrete "NIIZHB". Issue 39: Calculation and design of reinforced concrete structures]. Moscow, 1977, pp. 48-57.

17. ElGawady M. A., Dawood H. M. Analysis of segmental piers consisted of concrete filled FRP tubes. Engineering Structures, 2012, no. 38, pp. 142-152.

18. Hamrick C. FRP bridge decks: A green double-leaf. Roads \& Bridges. Roads \& Bridges, 2012, no. 3, pp. $46-51$.

19. Hoffard T. A., Malvar L. J. Fiber-reinforced polymer composites in bridges: a state-of-the-art report. Naval Facilities Engineering Service Center. Port Hueneme: NAVFAC, 2005. 38 p. Available at: https://archive.org/details/DTIC_ADA526493/mode/2up

20. Kendall D. Developments in FRP bridge design. Reinforced Plastics, 2010, no. 54 (3), pp. 38 - 42.

21. Potyrala P. B. Use of fibre-reinforced polymers in bridge construction. State of the art in hybrid and allcomposite structures. Barcelona, 2011. 93 p. Available at: https://upcommons.upc.edu/handle/2099.1/12353.

22. Watson R. J. Field Condition Surveys of FRP Applications on Bridges. Proceedings of the Second International Conference on Durability of Fibre Reinforced Polymer (FRP) Composites for Construction, Montreal, May 29-31. Sherbrooke, Université de Sherbrooke, 2002, pp. 597-606. 